\title{
Pendampingan Fikih Marital bagi Remaja Putus Sekolah
}

\author{
Bashori Alwi ${ }^{1}$, Muhtamilatur Rohmah², Moh. Shiddie Muhtadi ${ }^{3}$,
} Nuril Azizu Anggraini ${ }^{4}$, Siti Yusrohlana ${ }^{5}$, Devi Yunilasari ${ }^{6}$, Nurmasita ${ }^{7}$

Universitas Nurul Jadid, Probolinggo 1, 2, 3, 4, 5, 6, 7

\{bashorialwi@unuja.ac.id\}

Submission: 2021-02-20 Received: 2021-04-23 Published: 2021-04-30

Keywords:

Marital Fiqh, Family

Economic resilience,

Divorce

\begin{abstract}
Divorce has always been a phobia for married couples. The causes are almost the same, if not for economic factors, of course due to the lack of knowledge and ethics in the family. Therefore, this community service is carried out to reduce the number of divorces due to these three factors in Karanganyar Paiton village and Asembakor Kraksaan village, Probolinggo. The mentoring process uses the Participatory Action Research (PAR) approach, which begins with mapping the problem (diagnosis), planning movement (mapping), carrying out transformative movements (action), observing and evaluating (observe), and compiling theoritization (reflect). The results of this community service are; 1) provide awareness to the public about the importance of marital fiqh education and economic readiness in forming a harmonious family; 2) this activity also resulted in the formation of a family counseling center that can be used by the general public to share, consult and resolve family problems.
\end{abstract}

Abstrak. Perceraian selalu menjadi fobia bagi pasangan suami istri. Penyebabnya hampir memiliki kesamaan, jika bukan karena faktor ekonomi, tentu disebabkan minimnya pengetahuan dan etika dalam berkeluarga. Oleh sebab itu, Pendampingan ini dilakukan untuk mengurangi angka perceraian yang dilatarbelakangi oleh tiga faktor tersebut di desa Karanganyar Paiton dan desa Asembakor Kraksaan, Probolinggo. Proses pendampingan menggunakan pendekatan Participatory Action Research (PAR), yang diawali dengan memetakan persoalan (diagnosis), merencanakan gerakan (mapping), melaksanakan gerakan transformatif (action), pengamatan dan evaluasi (observe), dan menyusun teoritisasi (reflect). Hasil pendampingan ini adalah; 1) memberikan kesadaran kepada masyarakat tentang pentingnya edukasi fikih marital dan kesiapan ekonomi dalam membentuk keluarga harmonis; 2) kegiatan ini juga menghasilkan terbentuknya pusat konseling keluarga yang dapat dimanfaatkan oleh masyarakat secara 
umum untuk melakukan sharing, konsultasi dan penyelesaian dalam permasalahan keluarga.

\section{Pendahuluan}

Pernikahan merupakan fase penting dalam kehidupan manusia yang harus dipersiapkan secara matang, baik dari aspek materi, fisik, maupun mental. Persiapan ini dimaksudkan untuk menjamin keberlangsungan pernikahan kedua belah pihak, mewujudkan keluarga yang sakinah, mawaddah, dan rahmah, dan tidak berakhir dengan perceraian (Fathoni, 2018). Itulah sebabnya, negara telah mengeluarkan peraturan baru tentang batas minimal usia pernikahan dalam undang-undang Nomor 16 Tahun 2019 pasal 7 ayat (1), yaitu bahwa perkawinan dapat dilangsungkan bagi pria dan wanita yang telah mencapai usia minimal 19 tahun.(Presiden Republik Indonesia, 2019) Peraturan ini merupakan hasil revisi dari peraturan sebelumnya, yaitu UU Perkawinan Nonor 1 Tahun 1974 pasal 7 ayat (1), tentang batasan minimal wanita telah mencapai usia 16 tahun dan laki-laki mencapai 19 tahun (Presiden Republik Indonesia, 1974).

Semangat perubahan undang-undang di atas, sebagaimana pernyataan Andi Yuliani, dibentuk untuk memberikan hak-hak konstitusional bagi warga negara, yaitu pemberian hak pendidikan, ekonomi, sosial, dan kesehatan reproduksi yang tidak boleh dibedakan antara laki-laki dan perempuan (Badan Legislasi, 2019). Dalam konteks ini, Mufidah Ch memposisikan pendidikan sebagai asas dalam membangun rumah tangga, sebab keluarga menjadi tempat edukasi pertama bagi anggota keluarga yang lain, terlebih penanaman moral bagi putra-putrinya (Cholil, 2014). Lebih dari itu, Asniar Khumas memberikan kesimpulan dalam penelitiannya bahwa faktor tidak langsung yang berkontribusi pada intensi perceraian adalah ditentukan oleh tingkat pendidikan. Semakin tinggi tingkat pendidikan seorang istri, maka intensi perceraian akan semakin rendah (Khumas et al., 2015).

Pada ranah praktik di lapangan, undang-undang tersebut tidak banyak memberikan pengaruh terhadap pembatasan usia pernikahan. Hal ini misalnya terjadi pada masyarakat pedesaan. Wantjik, misalnya, menuturkan bahwa perkawinan dini di pedesaan sering kali terjadi pada golongan ekonomi menengah ke bawah dan tingkat pendidikan yang rendah. Sementara di perkotaan pernikahan dini terjadi pada remaja karena 
kahamilan di luar nikah (Wantjik Saleh, 2014). Lebih dari itu, dalam aspek sosiologi pedesaan, terdapat beberapa ciri yang dimiliki oleh maryarakat desa, yang salah satunya adalah, keinginan yang rendah untuk menggapai masa depan. Masyarakat pedesaan, terutama bagi yang rentan atas kemiskinan, cenderung memiliki keinginan yang sangat rendah di bidang pendidikan dan pekerjaan (Susilawati, 2012). Rendahnya tingkat pendidikan yang berkorelasi dengan kemiskinan ini menjadi faktor utama dari retaknya sebuah keluarga dan berakhir pada perceraian (Julijanto et al., 2016).

Dalam konteks mitigasi perceraian dan pembentukan ketahanan keluarga, maka diperlukan langkah konkret pendampingan terhadap dua karakter masyarakat pedesaan tersebut, yaitu lapisan masyarakat yang memiliki tingkat pendidikan rendah dan terdampak kemiskinan. Program dampingan ini akan menjadikan Desa Asembakor kec. Kraksaan dan desa Karanganyar kec. Paiton Kabupaten Probolinggo, Jawa Timur Indonesia, sebagai objek pengabdian. Pasalnya, meski secara geografis dua desa ini tidak berlokasi di pedalaman layaknya desa tertinggal lain, tetapi dalam data survei yang dilakukan penulis, pernikahan dini dan angka perceraian masih marak terjadi. Hal ini bertolak belakang dengan kondisi geografis desa Karangayar yang berada di lingkungan perguruan tinggi dan pesantren, tetapi masih terdapat kasus pernikahan dini akibat rendahnya pendidikan masyarakatnya. Setali tiga uang, meski desa Asembakor terletak di bagian kota Kraksaan memiliki, akan tetapi rendahnya ekonomi berkontribusi atas angka perceraian keluarga.

Berangkat dari kondisi masyarakat desa Karanganyar dan Asembakor di atas, penulis menginisiasi suatu kegiatan pendampingan kepada remaja putus sekolah dan keluarga rentan peceraian akibat ekonomi. Kegiatan ini bersifat pendampingan pelaksanaan program, yang diawali dengan survei, penguatan bidang fikih marital yang meliputi; 1) pembekalan keluarga sakinah; 2) tugas dan tanggung jawab suami istri; 3) pengelolaan aset desa untuk mewujudkan ekonomi keluarga mandiri; dan 4) konsultasi fikih keluarga. beberapa program ini diharapkan mampu memberikan mitigasi angka pernikahan dini dan perceraian dalam sebuah keluar. 


\section{Metode}

Pendampingan ini menggunakan pendekatan Participatory Action Research (PAR), yaitu suatu pendekatan yang berorientasi pada edukasi masyarakat dalam mengatasi masalah, transformasi perubahan sosial, dan pemenuhan kebutuhan masyarakat (Norman K. Denzin, 2011). Pada tahapan praktik pelaksanaannya, PAR memiliki beberapa prinsip yang harus diterapkan, yaitu; 1) mendorong masyarakat untuk terlibat langsung dalam rangkaian kegiatan. PAR tidak menjadikan masyarakat binaan sebagai objek, tetapi juga diposisikan sebagai subjek; 2) peneliti yang menjadikan PAR sebagai pendekatan harus memposisikan diri sebagai bagian dari masyarakat (insider), bukan mengamatinya dari luar (outsider). Dengan demikian, peneliti harus barbaur untuk sama-sama mencapai apa yang diharapkan terwujud dalam masyarakat (Knott, 2005); 3) penelitian model PAR berupaya menggabungkan antara kegiatan penelitian dan tindakan langsung yang dilakukan oleh masyarakat secara partisipatif. Pada tahapan ini, persoalan yang ingin diselesaikan dalam masyarakat muncul dari masyarakat sendiri; 4) Penelitian PAR mendorong keikutsertaan masyarakat secara aktif dalam kegiatan yang telah diagendakan. Dengan demikian, tujuan yang diharapkan bersama dapat terwujud dengan baik (MacDonald, 2012)

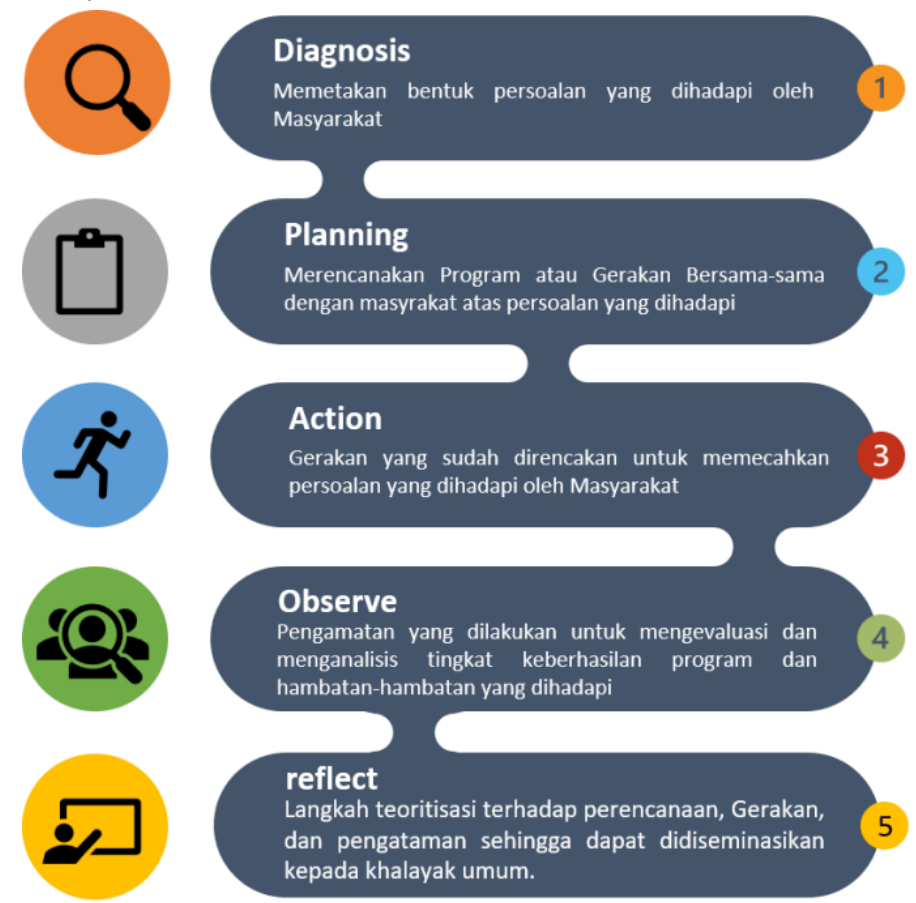

Gambar 1. Pendekatan PAR dalam Pendampingan Fikih Marital

Pendekatan PAR yang digunakan dalam pendampingan Fikih Marital Bagi Remaja Putus Sekolah di desa Karanganyar Paiton dan desa Asembakor Kraksaan ini memiliki beberapa tahapan; pertama diagnosis, yaitu langkah 
awal yang harus dilakukan untuk memetakan segala bentuk persoalan yang muncul dalam masyarakat. Pemetaan awal ini menjadi kunci bagi peneliti untuk mengetahui, mengenali dan berbaur dalam segala bentuk aktifitas masyarakat. Diagnosis terhadap dua desa yang menjadi objek pendampingan ini tidak perlu dilakukan lagi sebab keduanya telah menjadi desa binaan dan program strategis Universitas Nurul Jadid. Dengan demikian, peneliti telah mengetahui persoalan yang akan diselesaikan dan menjadi kebutuhan masyarakat.

Kedua planning, yaitu peneliti bersama-sama dengan komunitas masyarakat mengadendakan program riset dengan pendekatan Partisipatory Rural Aprasial (PRA). Pendekatan ini digunakan untuk memahami persoalan yang dihadapi oleh masyarakat dan mengorganisir atas terbentuknya kelompok-kelompok dalam masyarakat tersebut. pada tahapan planning ini, peneliti bersama dengan masyarakat menyusun strategi kegiatan untuk menyelesaikan problem yang telah dirumuskan di awal, yaitu menemukan langkah sistematis, menentukan pihak-pihak yang harus dilibatkan, dan mengorganisasikan masyarakat.

Ketiga action, yaitu suatu gerakan yang dimaksudkan untuk memecahkan problem secara kontinu dan bersifat partisipatif. Setelah peneliti melakukan perencanaan, langkah selanjutnya adalah mengimplementasikan rencana tersebut bersama-sama masyarakat, misalnya memberikan pemahaman tentang peran suami istri dalam membentuk keluarga sakinah dan strategi membangun ekonomi desa mandiri. Meski diorganisir oleh peneliti, tetapi proses pembelajaran kepada masyarakat harus tertanam dengan baik. Dengan demikian, terbangun pranata sosial baru daalam masyarakat tersebut yang kemudian mampu mengorganisir dirinya sendiri.

Keempat observe, yaitu langkah pengamatan yang harus dilakukan untuk memperhatikan dan menganalisis tingkat keberhasilan, kelemahan, dan kekurangan pendekatan yang digunakan dalam menyelesaikan persoalan. Di samping itu, hal-hal yang menghambat dan mendukung harus menjadi catatan dalam evaluasi kegiatan.

Kelima reflect, yaitu suatu langkah yang dilakukan oleh peneliti bersama dengan komunitas merumuskan teoritisasi perubahan sosial. Aksi dan gerakan yang telah dilakukan selama pendampingan direfleksikan sehingga menjadi rumusan teoritis akademik yang dapat disuguhkan dalam diseminasi publik. Pada tema pendampingan ini, langkah reflect berguna untuk 
mendeskripsikan dari tahap perencanaan, pelaksanaan, evaluasi dan temuan yang dihasilkan selama proses pendampingan (Moh. Ansori, Agus Afandi, Ries Dyah Fitriyah, Rizka Safriyani, 2021).

\section{Hasil dan Pembahasan}

Langkah awal yang dilakukan dalam pelaksanaan pendampingan ini, sesuai dengan pendekatan participatory action research (PAR), adalah diagnosis persoalan yang dihadapi oleh masyarakat. Sebelum melanjutkan pembahasan, untuk memudahkan pembaca, peneliti akan memberikan poin pada masing-masing tahapan sebagaimana berikut ini:

\section{a. Diagnosis}

Pada tahapan pelaksanaan diagnosis, peneliti menggunakan empat tahapan untuk mengenal, berbaur, dan menemukan persoalan yang dihadapi oleh masyarakat, yaitu assesment awal, inkulturasi, penggalian data, dan perumusan hasil riset. Assesment awal dimaksudkan untuk mendeskripsikan gambaran umum desa Asembakor Kraksaan dan desa Karanganyar Paiton Probolinggo, termasuk juga lokasi dan geografis kependudukannya. Peneliti tidak mendapatkan kesulitan pada tahapan ini bukan saja karena peneliti telah lama mengenal dua desa tersebut, akan tetapi juga jarak keduanya yang tidak berjauhan dengan tempat domisili peneliti. Di samping itu, karakter masyarakat pedesaan memiliki sifat yang homogen.

Peneliti melakukan tahapan assesment awal terhadap dua desa tersebut pada tanggal 19 Desember 2020 dan mendatangi kantor desa untuk meminta izin pengabdian. Bertemu langsung dengan sekretaris Desa, Rofi'i, dan ia menitipkan pesan kepada peneliti untuk tetap menjaga protokol kesehatan selama proses pelaksanaan dampingan. Setelah menyampaikan perizinan kepada pemerintah desa, peneliti mendatangi ketua RT dan RW untuk memperkenalkan maksud dan tujuan kedatangan peneliti.

Langkah berikutnya adalah inkulturasi, yaitu upaya peleburan diri peneliti dalam kegiatan kemasyarakatan, mengikuti acara seremonial, dan bahkan nongkrong dengan remaja desa. Dengan demikian, masyarakat desa memberi kepercayaan kepada peneliti dan beberapa tokoh desa membuka diri untuk menceritakan segala bentuk problem yang dialami oleh rejama desa. Proses inkulturasi terlaksana dengan baik salah satunya juga karena dibantu oleh pejabat desa; bapak Rofi'i, sekretaris desa Karanganyar, dan Bapak H. Zainullah, kepala desa Asembakor Kraksaan.

Selanjutnya, penggalian data dilakukan dengan cara wawancara semi terstruktur kepada stakeholders, remaja desa putus sekolah, dan sejumlah keluarga terdampak perceraian karena faktor ekonomi. Selain wawancara, peneliti juga melakukan mapping desa, diagram venn, dan penggalian data-data lain yang dianggap penting. 
Selama proses penggalian data, peneliti juga melaksanakan focus grup discussion bersama remaja putus sekolah yang akan melangsungkan pernikahan dan keluarga yang terdampak perceraian. Hal ini penting dilakukan untuk memberikan pemahaman mereka akan pentingnya pendidikan fikih marital pra pernikahan dan diharapkan adanya gerakan konkret yang dapat memecahkan persoalan. FGD pertama dilakukan bersama remaja putus sekolah. Pada kegiatan tersebut, peneliti bersama tim samara parenting dari Surabaya memberikan penguatan pengetahuan fikih marital dan pentingnya pendidikan dalam membentuk keluarga sakinah. FGD berikutnya dilakukan bersama keluarga terdampak perceraian. Pada sesi ini, selain menghadirkan tim samara parenting, peneliti juga mengajak tim pemberdayaan ekonomi GreenThink untuk memberikan pembekalan di bidang penguatan ekomoni keluarga mandiri.

Setelah penggalian data tentang persoalan pernikahan remaja putus sekolah dan perceraian akibat faktor ekonomi di masyarakat desa Karanganyar Paiton dan desa Asembakor Kraksaan, maka langkah selanjutnya adalah merumuskan hasil FGD untuk dijadikan sebagai gerakan strategis yang dapat menyelesaikan persoalan. Untuk memberikan pemahaman kepada remaja putus sekolah dan perceraian akibat faktor ekonomi, mereka sepakat untuk melaksanakan suatu kegiatan, yaitu edukasi fikih marital dan penguatan bidang ekonomi mandiri.

\section{b. Planning}

Setelah pelaksanaan diagnosis yang terdiri dari assement awal, inkulturasi, penggalian data, dan perumusan persoalan, maka peneliti bersama dengan masyarakat berupaya untuk merencanakan gerakan yang tepat dan jitu dalam menyelesaikan masalah yang terjadi pada pernikahan remaja putus sekolah dan perceraian karena faktor ekonomi di desa Karanganyar Paiton dan desa Asembakor Kraksaan Probolinggo.

Tabel 1. Planning hasil Mapping

\begin{tabular}{llll}
\hline No & $\begin{array}{l}\text { Masalah yang } \\
\text { dihadapi }\end{array}$ & $\begin{array}{l}\text { Harapan yang } \\
\text { diinginkan }\end{array}$ & $\begin{array}{l}\text { Strategi Mencapai } \\
\text { harapan }\end{array}$ \\
\hline 01 & Maraknya & Masyarakat menyadari & Memberikan edukasi \\
& pernikahan pada & tentang pentingnya & kepada masyarakat \\
& usia wajib belajar & pendidikan bagi masa & tentang pentingnya \\
& dan tingginya & depan anak dan & pembinaan fikih \\
& angka perceraian & keberlangsungan & marital, pendidikan \\
& karena faktor & keluarga & dan pekerjaan sebagai \\
& ekonomi di Desa & & bekal dalam \\
& Asembakor & & \\
& Kraksaan. & & berkeluarga \\
\hline 02 & Tidak adanya & Terlaksanakan & kembentuk pusat \\
& penyuluhan atau & kegiatan penyuluhan, & konseling bagi remaja \\
\hline
\end{tabular}




\begin{tabular}{|c|c|c|c|}
\hline & $\begin{array}{l}\text { pembinaan } \\
\text { nonformal } \\
\text { terhadap remaja } \\
\text { putus sekolah }\end{array}$ & $\begin{array}{l}\text { pendampingan dan } \\
\text { edukasi terhadap } \\
\text { remaja putus sekolah }\end{array}$ & $\begin{array}{l}\text { pra nikah di Desa } \\
\text { Karanganyar Paiton } \\
\text { Probolinggo }\end{array}$ \\
\hline 03 & $\begin{array}{l}\text { Tidak adanya } \\
\text { kebijakan dari } \\
\text { pemerintah } \\
\text { desa/penyuluh } \\
\text { agama di Desa } \\
\text { tentang; } 1 \text { ) } \\
\text { undang-undang } \\
\text { Nomor } 16 \text { Tahun } \\
\text { 2019 pasal } 7 \text { ayat } \\
\text { (1); 2) kebijakan } \\
\text { tentang batas usia } \\
\text { pernikahan }\end{array}$ & $\begin{array}{l}\text { Terlaksananya } \\
\text { sosialiasi undang- } \\
\text { undang Nomor } 16 \\
\text { Tahun } 2019 \text { pasal } 7 \\
\text { ayat (1) bagi seluruh } \\
\text { lapisan masyarakat } \\
\text { dan adanya kebijakan } \\
\text { dari pemerintah desa } \\
\text { tentang pembatasan } \\
\text { usia pernikahan }\end{array}$ & $\begin{array}{l}\text { Melakukan sosialisasi } \\
\text { dan edukasi terhadap } \\
\text { undang-undang } \\
\text { pembatasan usia } \\
\text { pernikahan kepada } \\
\text { lapisan masyarakat }\end{array}$ \\
\hline
\end{tabular}

Tabel di atas menunjukkan bahwa persoalan pada dua desa yang menjadi fokus pengabdian tidaklah sama, yaitu desa Asembakor dominasi persoalan pada tingginya angka perceraian karena disebabkan faktor ekonomi, sementara problem yang ada di masyarakat desa Karanganyar adalah pernikahan dini yang dilakukan oleh remaja putus sekolah. Dengan adanya pembedaan ini, maka langkah dan strategi yang digunakan dalam menyelesaikan problem juga berbeda.

Pertama, gerakan strategis yang dilaksanakan di desa Karanganyar Paiton adalah edukasi fikih marital bagi pernikahan remaja putus sekolah. Hal ini dikarenakan oleh data yang menunjukkan bahwa selama tahun 2017-2021 seetidaknya terdapat 17 pernikahan dini, atau pernikahan pada anak usia sekolah. Sementara di desa Asembakor Kraksaan, angka perceraian yang disebabkan oleh faktor ekonomi lebih dominan.

Kedua, di dua desa tersebut tidak adanya penyuluhan atau pembinaan nonformal terhadap remaja putus sekolah, baik yang dilaksanakan oleh pemerintah desa, maupun oleh lembaga terkait. Oleh sebab itu, gerekan strategis yang direncanakan adalah melaksanakan penyuluhan, pendampingan dan edukasi terhadap pernikahan remaja putus sekolah bagi masyarakat desa Karanganyar dan pendampingan peningkatan ketahanan ekonomi keluarga di desa Asembakor Kraksaan. Lebih dari itu, harapan pendampingan ini juga menginisiasi atas terbentuknya lembaga konseling keluarga dan konsultasi bisnis keluarga. 
Ketiga, di dua desa, baik desa Asembakor Kraksaan dan desa Karanganyar Paiton, belum terlaksana kegiatan sosialisasi atas undang-undang Nomor 16 Tahun 2019 pasal 7 ayat (1); 2) kebijakan tentang batas usia pernikahan, sehinga menyebabkan masyarakat tidak mengetahui dengan jelas aturan pernikahan. Di samping itu, dua desa tersebut tidak mendapatkan pelayanan tentang usaha mandiri untuk menciptakan ketahanan ekonomi keluarga belum tersentuh, padahal apabila melihat potensi desa yang dimiliki sangat memungkinkan untuk dikembangkan dan menjadi sumber pemasukan baru bagi keluarga.

\section{c. Action}

Sesuai dengan planning yang telah direncanakan antara peneliti dengan masyarakat, utamanya dengan para remaja putus sekolah yang akan melangsungkan pernikahan dan masyarakat yang mengalami perceraian karena faktor ekonomi, maka sejumlah program yang akan dilaksanakan adalah sebagai berikut:

1) Edukasi Fikih Marital

Pelaksanaan kegiatan ini berlangsung pada hari Selasa tanggal 05 Januari 2021 yang bertempat di Masjid Jami' Baitis Salam Karanganyar Paiton. Pada kegiatan tersebut, turut hadir Ketua Ta'mir Masjid, Remaja Masjid, dan para remaja putus sekolah yang berencana menempuh jenjang pernikahan. Kegiatan ini diisi langsung oleh Holilurrahman, direktur Samara Parenting dari Surabaya. Holilurrahman menjelaskan tentang pentingnya pendidikan, saling memahami peran masing-masing pasangan dan kepercayaan sebagai modal dalam membangun rumah tangga sakinah. Kegiatan berlangsung khidmat, dimulai sejak pukul 09.00 sampai dengan pukul 15.40 WIB. 


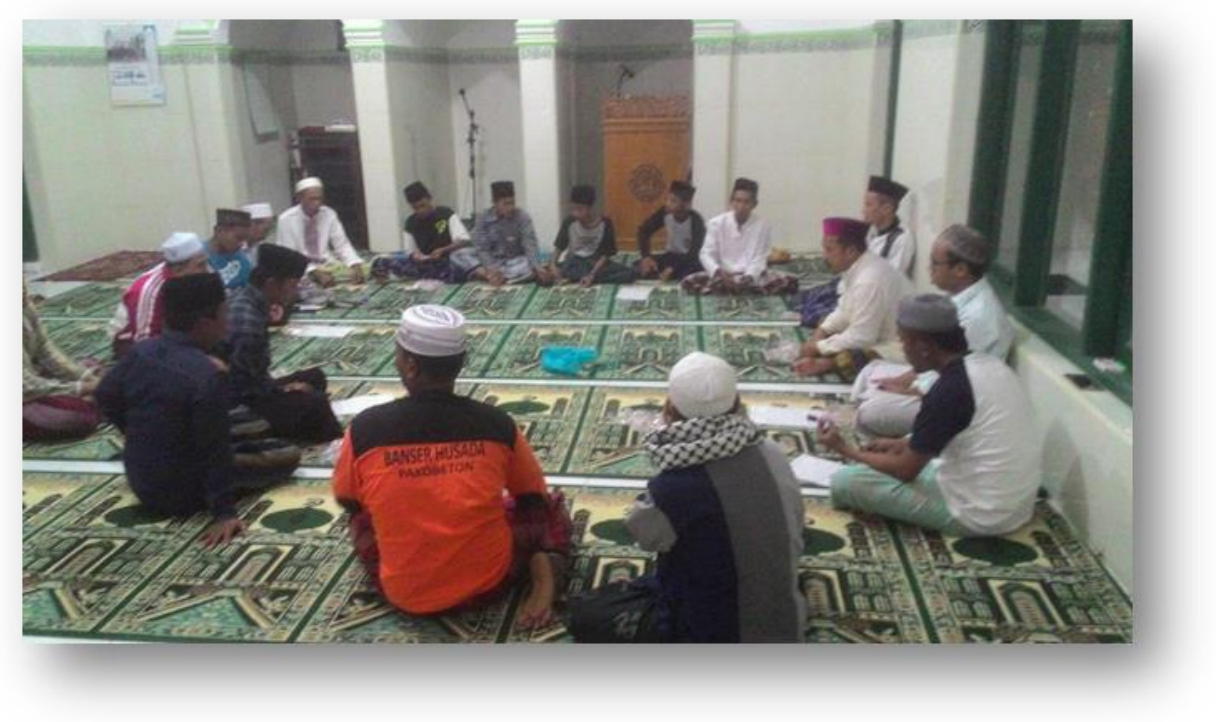

Gambar 2. Edukasi Fikih Marital

Dalam waktu yang berbeda, yakni pada hari Rabu tanggal 06 Januari 2021, kegiatan serupa juga berlangsung di Masjid Attaqwa untuk masyarakat Desa Asembakor. Kegiatan didesain tidak hanya pematerian tentang kewirausahaan, tetapi juga melakukan mapping potensi desa yang dapat dikembangkan dalam sektor ekonomi. Kegiatan yang diperuntukkan bagi perceraian keluarga karena faktor ekonomi ini dinarasumberi oleh Arif Rahman Hakim, penggerak Kedaulatan Bumi Santri, Probolinggo, yang dimulai pada pukul 09.30 sampai dengan pukul 16.00 WIB.

2) Pembentukan Pusat Konseling

Sebagai tindak lanjut dari edukasi fikih marital dan pendampingan ketahanan ekonomi keluarga, masyarakat desa Karanganyar Paiton dan desa Asembakor Kraksaan menginisiasi terbentuknya pusat konseling di bidang keluarga dan ekonomi kreatif. Masing-masing pusat konseling dikoordinasi oleh Pusat bantuan Hukum dan Lab Based Education Ekonomi Universitas Nurul Jadid. Pusat konseling ini beroperasi setiap hari Juma'at dan Rabu. 


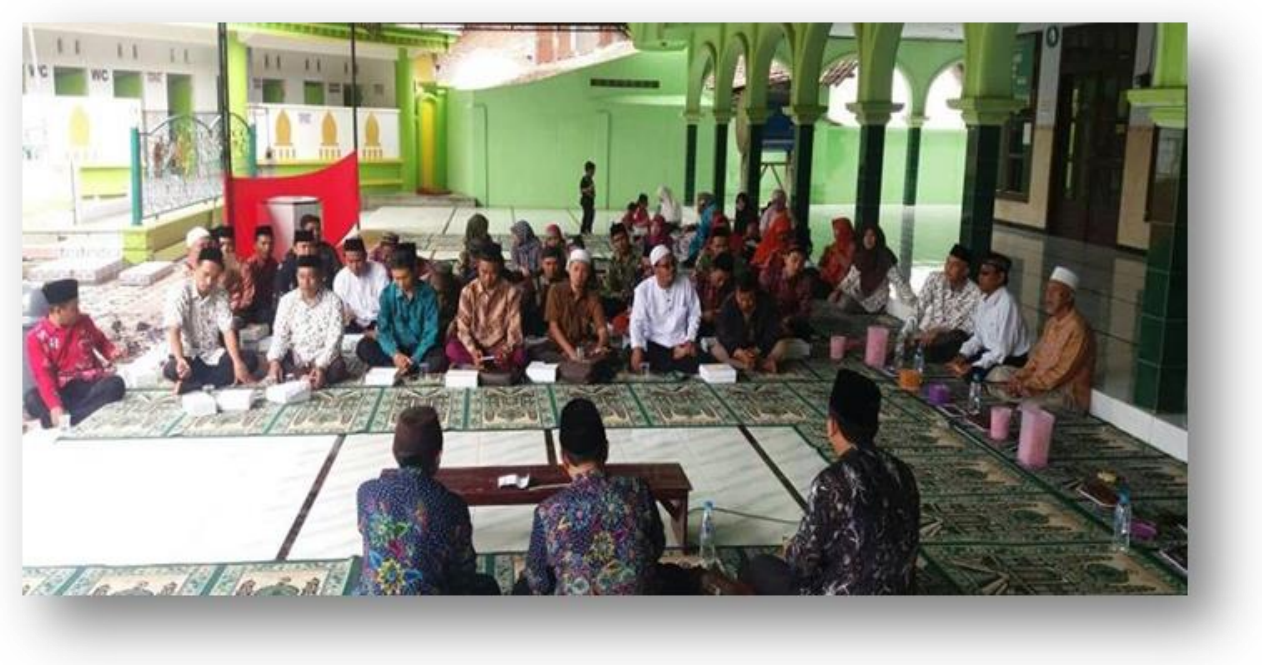

Gambar 3. Pembentukan Pusat Konseling Keluarga

3) Melakukan advokasi

Setelah membentuk pusat konseling di masing-masing desa, langkah awal yang dilakukan adalah sosialisasi undang-undang Nomor 16 Tahun 2019 pasal 7 ayat 1 tentang batasan usia pernikahan kepada seluruh lapisan masyarakat, menentukan fasilitator yang bertugas pada pusat konseling, dan melakukan edukasi baik kepada masyarakat yang datang ke pusat konseling ataupun fasilitator mendatangi kegiatan ritual kemasyarakatan, seperti sarwah, tahlilan dan acara adat lainnya.

\section{d. Observe}

Tujuan utama dari pendampingan adalah transformasi perubahan bagi masyarakat dan meningkatkan kesadarannya. Proses edukasi sebagaimana yang telah dilakukan di atas bertujuan untuk mengubah pola pikir masyarakat yang pada tahapan selanjutnya masyarakat memiliki keinginan sendiri untuk mengubah kepada kondisi yang lebih baik. Oleh sebab itu, kegiatan pendampingan tidak dapat dilaksanakan sekali jadi. Dengan kata lain, pendampingan harus berjalan kontinu dan simultan (Mundiri et al., 2019).

Dalam rangka mewujudkan ketercapaian tujuan yang diingingkan masyarakat, maka langkah selanjutnya yang dilakukan oleh peneliti adalah melakukan evaluasi. Evaluasi dilakukan dalam dua hal, yakni pertama adalah untuk menjamin bahwa kegiatan FGD dan edukasi benar-benar memiliki pengaruh langsung kepada masyarakat; kedua, kegiatan yang telah dilaksanakan benar-benar membawa perubahan bagi masyarakat. 
Pelaksanaan evaluasi dilakukan dengan menggunakan teknik Most Significant Change, yaitu tanggapan atau cerita tentang perubahan yang terjadi pada masyarakat penerima manfaat (Davies Rick, 2013). Dari kegiatan edukasi fikih marital, masyarakat menilainya sebagai sebuah kegiatan penyadaran akan pentingnya pendidikan. Selanjutnya, masyarakat juga menyadari bahwa pernikahan harus dipersiapakan dari aspek usia, kesehatan reproduksi, materi, dan psikis. Dengan mempersiapkan hal tersebut setidaknya akan memberikan pengaruh pada keharmonisan dalam berumah tangga.

Selain itu, khusus bagi masyarakat desa Asembakor, mereka menyadari bahwa potensi alam yang memadai perlu dikembangkan menjadi lahan bisnis agrikultur. Nur Syifa' mengakui bahwa selama ini masyarakat tidak menyadari bahwa lahan yang subur, pekarangan yang kosong, dan bahkan halaman rumah yang dapat dimanfaatkan untuk lahan bisnis sebagai lahan yang dapat dikembangkan. Dengan pemanfaatan lahan kosong ini, Nur Syifa' yakin bahwa kemiskinan yang dialami masyarakat dapat dikikis dengan pemanfaatan lahan-lahan kosong tadi.

Pembentukan pusat konseling juga mendapat tanggapan positif dari masyarakat. Meski masih beroperasi kurang dari sebulan, tetapi minat dan spirit masyarakat untuk sharing dan menyelesaikan persoalan rumah tangga dan ekonomi mulai terlihat. Pamong desa bidang administrasi, M. Ma'soem, menilai positif pusat konseling ini. Menurutnya, advokasi dan edukasi terhadap masyarakat dapat dilakukan melalui lembaga ini. berikut ini adalah tabel evaluasi dengan teknik Most Significant Change, yang datanya dihasilkan dari wawancara dengan masyarakat binaan.

Table 2. Evaluasi Program dengan Teknik Most Significant Change

\begin{tabular}{llllll}
\hline No & Kegiatan & Tanggapan & Manfaat & Perubahan & Harapan \\
\hline 01 & Edukasi & Bermanfaa & Menciptaka & Meningkatny & Pendampin \\
& Fikih & t bagi & n pola baru & a kesadaran & gan dapat \\
& Marital & masyaraka & dalam & masyarakat & dilakukan \\
& t sebagai & proses & tentang & secara \\
& bentuk & advokasi & pentingnya & kontinu \\
& penyadara & dan edukasi & mempersiapa & dan \\
& n diri yang & terhadap & kan diri pada & simultan, \\
& berpengar & pendampin & jenjang & agar angka \\
& uh pada & gan fikih & pernikahan, & perceraian \\
& perubahan & marital & dari aspek & semakin \\
& lebih baik & & pendidikan, & menurun. \\
& & & kekuatan & \\
\hline
\end{tabular}




\begin{tabular}{|c|c|c|c|c|c|}
\hline & & & & $\begin{array}{l}\text { materi, psikis } \\
\text { dan } \\
\text { kesehatan } \\
\text { reproduksi }\end{array}$ & \\
\hline 02 & $\begin{array}{l}\text { Pembentu } \\
\text { kan Pusat } \\
\text { Konseling }\end{array}$ & $\begin{array}{l}\text { Bermanfaa } \\
\text { t bagi } \\
\text { masyaraka } \\
\text { t agar } \\
\text { memliki } \\
\text { wadah } \\
\text { untuk } \\
\text { sharing, } \\
\text { penyelesai } \\
\text { an secara } \\
\text { kekeluarga } \\
\text { an, dan } \\
\text { proses } \\
\text { advokasi } \\
\text { atas segala } \\
\text { bentuk } \\
\text { persoalan }\end{array}$ & $\begin{array}{l}\text { Memberika } \\
\text { n layanan } \\
\text { kepada } \\
\text { masyarakat }\end{array}$ & $\begin{array}{l}\text { Masyarakat } \\
\text { agar } \\
\text { menyadari } \\
\text { pentingnya } \\
\text { pendidikan } \\
\text { fikih marital } \\
\text { sebelum } \\
\text { menjalani } \\
\text { pernikahan } \\
\text { dan } \\
\text { pentingnya } \\
\text { penguatan } \\
\text { ekonomi } \\
\text { menuju } \\
\text { ketahanan } \\
\text { ekonomi } \\
\text { keluarga }\end{array}$ & $\begin{array}{l}\text { Adanya } \\
\text { pembentu } \\
\text { kan pusat } \\
\text { konseling } \\
\text { dalam } \\
\text { bidang } \\
\text { keluarga } \\
\text { dan } \\
\text { penguatan } \\
\text { ekonomi }\end{array}$ \\
\hline 03 & $\begin{array}{l}\text { Advokasi } \\
\text { dan } \\
\text { edukasi } \\
\text { kepada } \\
\text { masyarak } \\
\text { at }\end{array}$ & $\begin{array}{l}\text { Bermanfaa } \\
\text { t karena } \\
\text { dapat } \\
\text { membantu } \\
\text { menumbu } \\
\text { h- } \\
\text { kembangk } \\
\text { an } \\
\text { ekonomi } \\
\text { keluarga } \\
\text { dan } \\
\text { layanan } \\
\text { keluarga } \\
\text { sakinah }\end{array}$ & $\begin{array}{l}\text { Proses } \\
\text { layanan } \\
\text { dalam } \\
\text { advokasi } \\
\text { dan edukasi } \\
\text { dapat } \\
\text { dipahami }\end{array}$ & $\begin{array}{l}\text { Masyarakat } \\
\text { agar } \\
\text { mengalami } \\
\text { perubahan } \\
\text { mindset dari } \\
\text { abai terhadap } \\
\text { pendidikan, } \\
\text { pernikahan } \\
\text { dini, dan } \\
\text { perjodohan. }\end{array}$ & $\begin{array}{l}\text { Pemerinta } \\
\text { h desa } \\
\text { dapat } \\
\text { memberika } \\
\text { n support } \\
\text { berupa } \\
\text { kebijakan } \\
\text { dan } \\
\text { regulasi } \\
\text { tentang } \\
\text { pembatasa } \\
\text { n usia } \\
\text { pernikahan }\end{array}$ \\
\hline
\end{tabular}

Sumber: CV. Karunia, 2018

\section{e. Reflect}

Sebagai refleksi kegiatan, secara spesifik penelitian ini berfolus pada upaya pendampingan terhadap pernikahan remaja putus sekolah di desa Karanganyar Paiton dan perceraian keluarga karena faktor ekonomi di desa Asembakor Kraksaan, yang kedua desa tersebut terletak di kabupaten Probolinggo. Pengorganisiran kegiatan ini menggunakan pendekatan 
Participatory Acion Research (PAR) karena dua alasan; 1) adanya temuan data permasalahan yang timbul dalam masyarakat; dan 2) masyarakat membutuhkan penyelesaian atas persoalan tersebut untuk meminimalisir angka pernikahan dini, pernikahan remaja putus sekolah, dan kasus perceraian yang disebabkan oleh faktor ekonomi.

Masyarakat binaan dalam konteks pendekatan Participatory Acion Research (PAR) diposisikan sebagai subjek penelitian, bukan sebagai objek. Dengan demikian, segala proses penelitian dan pendampingan dilakukan bersama-sama dengan masyarakat sekaligus permasalahan yang muncul juga bersumber dari masyarakat. Dari hasil diagnosis dan mapping dua desa binaan tersebut, terdapat dua masalah krusial yang dihadapi oleh masyarakat, yaitu tingginya angka pernikahan remaja putus sekolah dan perceraian akibat faktor ekonomi. Dengan demikian, gerakan yang dilakukan adalah mengorganisir masyarakat atas terbentuknya edukasi fikih marital dan penguatan ketahanan ekonomi keluarga serta mendorong atas terbentuknya pusat konseling keluarga.

Mitigasi perceraian karena faktor ekonomi dilakukan dengan cara edukasi dan advokasi kepada masyarakat desa Karanganyar Paiton Probolinggo. Edukasi dilakukan dengan cara pemberian materi tentang fikih marital yang meliputi; 1) pembekalan keluarga sakinah; 2) tugas dan tanggung jawab suami istri; 3) urgensi pendidikan dalam membentuk keluarga harmonis. Sementara penanggulangan perceraian karena faktor ekonomi dilakukan dengan penguatan ekonomi kreatif berbasis agrikultur.

Selain kegiatan dampingan dan pengabdian ini bertujuan mengedukasi masyarakat dan pemberdayaan ketahanan ekonomi keluarga, tentu secara sosial juga mengimplementasikan nilai-nilai ajaran Islam, yaitu peduli dan memberikan manfaat kepada masyarakat secara luas. Dalam konteks ini, alQur'an pada Surat al-Nūr: 32-33, menjelaskan sebagai berikut:

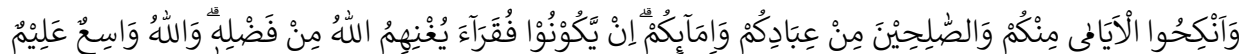

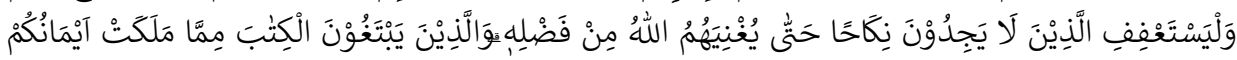

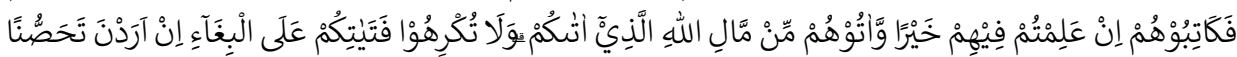

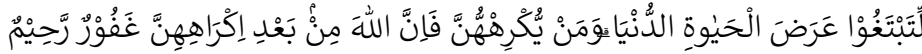

Artinya:

32. Dan nikahkanlah orang-orang yang masih membujang di antara kamu, dan juga orang-orang yang layak (menikah) dari hamba-hamba sahayamu yang laki-laki dan perempuan. Jika mereka miskin, Allah akan memberi 
kemampuan kepada mereka dengan karunia-Nya. Dan Allah Maha Luas (pemberian-Nya), Maha Mengetahui.

33. Dan orang-orang yang tidak mampu menikah hendaklah menjaga kesucian (diri)nya, sampai Allah memberi kemampuan kepada mereka dengan karunia-Nya. Dan jika hamba sahaya yang kamu miliki menginginkan perjanjian (kebebasan), hendaklah kamu buat perjanjian kepada mereka, jika kamu mengetahui ada kebaikan pada mereka, dan berikanlah kepada mereka sebagian dari harta Allah yang dikaruniakan-Nya kepadamu. Dan janganlah kamu paksa hamba sahaya perempuanmu untuk melakukan pelacuran, sedang mereka sendiri menginginkan kesucian, karena kamu hendak mencari keuntungan kehidupan duniawi. Barangsiapa memaksa mereka, maka sungguh, Allah Maha Pengampun, Maha Penyayang (kepada mereka) setelah mereka dipaksa.

Berkaitan dengan ayat ini, Aḥmad Mușțafā al-Marāghī memberikan penjelasan bahwa salah satu kewajiban umat Islam adalah membantu pernikahan seseorang yang sudah mencapai usia nikah. Apabila seseorang tersebut tidak mampu secara ekonomi, maka kewajiban umat Islam untuk memberikan kemudahan baik secara materi atau sekedar memberikan jalan untuk mendapatkan materi tersebut (Al-Marāghī, 1946).

Secara institusional, program pendampingan dan edukasi ini merupakan bagian dari program strategis Universitas Nurul Jadid Probolinggo yang berorientasi pada nilai kebermaatan kepada masyarakat. Dalam sambutannya, rektor, KH. Abd. Hamid Wahid, selalu menegaskan bahwa ouput dan outcome dari proses tridharma perguruan tinggi adalah memberikan manfaat kepada masyarakat.

\section{Kesimpulan}

Kegiatan pendampingan yang dilaksanakan dalam pengabdian kepada masyarakat ini ada dua bentuk kegiatan, yaitu pendampingan terhadap pernikahan remaja putus sekolah di desa Karanganyar Paiton dan pemberdayaan bagi kasus perceraian yang dilatarbelakangi ekonomi di desa Asembakor Kraksaan, Probolinggo. Kegiatan pendampingan di desa Karanganyar dilakukan dengan dua cara, yaitu edukasi fikih marital dan pembentukan pusat konseling keluarga. Sementara di desa Asembakor pendampingan dilakukan dengan desain pemberdayaan ekonomi berbasis agrikultur dan pembentukan pusat konseling ketahanan ekonomi keluarga. 
Berdasarkan hasil evaluasi dan observasi yang dilakukan, kegiatan ini memberikan pengaruh dalam mentransformasi kesadaran pentingnya edukasi fikih marital dan kesiapan ekonomi dalam membentuk keluarga harmonis. Sebagai tindakan berkesinambungan, kegiatan ini telah menghasilkan pusat konseling yang dapat dimanfaatkan oleh masyarakat secara umum untuk melakukan sharing, konsultasi dan penyelesaian dalam permasalahan keluarga.

\section{Referensi}

Al-Marāghī, A. M. (1946). Tafsīr al-Marāghī (18th ed.). al-Bābī al-Halabī.

Badan Legislasi. (2019). 19 Tahun Jadi Batas Usia Minimal Lakukan Pernikahan.

Https://Www.Dpr.Go.Id/Berita/Detail/Id/25914/t/19+Tahun+Jadi+Bata s+Usia+Minimal+Lakukan+Pernikahan.

Cholil, M. (2014). Psikologi keluarga Islam berwawasan gender. UIN-Maliki Press.

Davies Rick, D. J. (2013). The Most Significant Change (MSC) TEchnique: A Guide to Its Use (205). April, 1-139. https://doi.org/10.13140/RG.2.1.4305.3606

Fathoni, A., \& Fathoni, A. (2018). Perkawinan Anak Di Bawah Umur dalam Perspektif Hukum Islam dan Sosiologi Hukum. AT-TURAS: Jurnal Studi Keislaman, 4(1), 44-57. http://jurnal.iainuruljadid.ac.id/index.php/atturas

Fawaid, A. (2019). Filologi Naskah Tafsîr Bi Al-Imlâ' Surat Al-Baqarah Karya Kyai Zaini Mun'Im. Jurnal Studi IImu-IImu Al-Qur'an Dan Hadis, 20(2), 143. https://doi.org/10.14421/qh.2019.2002-02

Indonesia, P. R. (1974). UNDANG-UNDANG REPUBLIK INDONESIA NOMOR 1 TAHUN 1974 TENTANG PERKAWINAN. 2.

Julijanto, M., Masrukhin, M., \& Hayatuddin, A. K. (2016). Dampak Perceraian dan Pemberdayaan Keluarga Studi Kasus di Kabupaten Wonogiri. BUANA GENDER: Jurnal Studi Gender Dan Anak, 1(1), 55. https://doi.org/10.22515/bg.v1i1.71

Khumas, A., Prawitasari, J. E., \& Retnowati, S. (2015). Model Penjelasan 
Intensi Cerai Perempuan Muslim di Sulawesi Selatan. Jurnal Psikologi, 42(3), 189. https://doi.org/10.22146/jpsi.9908

Knott, K. (2005). Spatial theory and method for the study of religion. Temenos, 41(2), 153-184. https://doi.org/10.33356/temenos.4778

MacDonald, C. (2012). Understanding participatory action research: A qualitative research methodology option. The Canadian Journal of Action Research, 13(2), 34-50.

Moh. Ansori, Agus Afandi, Ries Dyah Fitriyah, Rizka Safriyani, H. F. (2021). Pendekatan-pendekatan dalam University-Community Engagement (W. B. Z. Siregar (ed.)). UIN SUNAN AMPEL PRESS.

Mundiri, A., Fawaid, A., \& Syamsuri. (2019). Women Empowerment Through Mangrove-Based And Fishery Products In Paiton Probolinggo. Proceeding International Conference on University-Community Engagement, 1(vol.3 no.1, 2018), 52-63.

Norman K. Denzin, Y. S. L. (2011). handbook of qualitative research (Fourth edi). SAGE. https://search.library.wisc.edu/catalog/9910109320302121

Presiden Republik Indonesia. (2019). Undang-undang Republik Indonesia Nomor 16 Tahun 2019 tentang Perubahan atas Undang-undang Nomor 1 Tahun 1974 tentang Perkawinan (Issue 006265).

Susilawati, N. (2012). Interaksi desa-kota dan permasalahannya. In Sosiologi Pedesaan.

Wantjik Saleh, K. (2004). Hukum perkawinan Indonesia. Sinar Grafika. 